\title{
Influence of Transformational Economic Processes on Marketing Management by an International Diversified Conglomerate Enterprise
}

\author{
Alona Tanasiichuk ${ }^{1 a}$, Olha Hromova ${ }^{2 a}$, Anastasiia Abdullaieva ${ }^{3 a}$, Yulia \\ Holovchuk $^{4 a}$, Kateryna Sokoliuk ${ }^{5 a}$
}

\begin{abstract}
In this article it is substantiated the necessity of radical changes study in the practice of domestic agricultural enterprises managing, creation of a new functional and organizational structure that will maximally facilitate the marketing strategy of business diversification by the agrarian enterprise of Ukraine. It is analyzed agrarian enterprises efficiency of activity under the conditions of the transformation processes, it is determined that the leaders of the domestic and world markets of agrarian products are agroholdings with a rigid management structure, and their marketing goals are a decisive factor while making choice of markets under the conditions of diversification activities. It is substantiated that the formation of an international diversified company of agrarian business provides equally to participating enterprises the use of common resources, redistribution of resources between structural units operating on one financial result, the possible loss of one enterprise is compensated by the profit of the group as a whole. Reformation of agrarian enterprises of Ukraine process is analyzed; in particular, in the case of farms in the context of international business diversification; it is determined the necessity of creating a new organizational structure of management by the agrarian enterprise. It is grounded the creation of a functional and organizational mechanism for an international diversified conglomerate enterprise activity in order to ensure the stability of its functioning under the conditions of the transformation processes.

It is proposed a new structure of functional and organizational management an international diversified conglomerate company on the basis of the developed marketing mechanism of enterprise management under the conditions of international diversification. It is substantiated that in Ukraine, the formation of such new international diversified conglomerate enterprises from small enterprises, by grouping farms (which by their number in Ukraine is most) will provide a positive result from overcoming the grinding of domestic agrarian business, consolidation of the agrarian sector and creating the opportunity to benefit from the budget of Ukraine from international diversified conglomerate business structures.
\end{abstract}

Keywords: transformational economic processes, international marketing, globalization, marketing management, international diversified conglomerate enterprise, business consolidation.

\section{Introduction}

In the transformation of economic processes in Ukraine require changes functional-organizational forms of agricultural enterprises. Their traditional form does not meet the requirements of the modern marketing environment, processes Informatization of society in the modern economic process, and the selection of the

| ${ }^{1}$ Doctor of Economics Sciences, Associate Professor of the Department of Marketing and Advertising, 2Ph.D. in Economics, Associate Professor of the Marketing and Advertising Department.

${ }^{3}$ Ph.D. in Economics, Assistant of the Finance Department.

${ }^{4} \mathrm{Ph} . \mathrm{D}$. in Economics, Senior Lecturer of the Department of Marketing and Advertising.

5Ph.D. in Economics, Senior Lecturer of the Department of Marketing and Advertising.

ainnytsia Trade and Economics Institute, KNTEU, Ukraine. 
organizational structure of management of an agricultural enterprise associated with the process of marketing strategy implementation that depend on the level of internationalization of its activities. In countries that are developing agricultural the business requires the processing industry. In economically developed countries the dominant form of business organization of agricultural enterprises are farming economy. In the countries with transit economy is changing economic relations of agricultural enterprises in market conditions, some of these countries have the necessary conditions for active entry into international markets [1, p. 56, 6]. Due to the fact that Ukraine has significant potential for employment priority in the international markets of agricultural products, the successful implementation of activities in terms of international diversification is happening due to the quality formation of diversified structures of agricultural business. It is necessary to study reflect such a radical change in the practice of management of domestic agrarian enterprises, and the creation of new functional organizational structure that will best promote the implementation of the agricultural enterprise of Ukraine marketing diversification strategy business.

\section{Analysis of the Research and the Problem Statement}

Some directions the transformation of the economy from the point of view of General laws of development economic processes have found their coverage in the works economists $[1-11]$. The work of these authors deals with the direction of transformation processes that affect the sustainability of the operation domestic enterprises, however, the essence of enterprise transformation type, its development has not yet found a deep understanding and theoretical justification in the agricultural sector of the economy. The result the passage trasformazioni stages in the agricultural sector should be the choice of agricultural enterprises, optimum marketing strategy the problem of realization which will be the choice of ways and revitalization on domestic and international markets $[6,8]$.

The relevant issue is the choice of the functional organizational forms of agricultural enterprises in the conditions of international diversification. In each case, the formation of diversified structures agricultural business it is necessary to develop the basic criteria of diversification based on the analysis of activity of an agrarian company. Analyzing efficiency of agrarian enterprises in the conditions of the flow transformation processes, can draw conclusions about what leaders domestic and world markets of agricultural products are agricultural holdings which have rigid management structure, and their marketing objective is crucial factor in the selection of markets in terms of diversification of activities.

Practice of functioning of agricultural enterprises in both the market and transformation economies is going through revolutionary changes, involving ensure the sustainability of their operation through the application of the marketing mechanism of enterprise management, according to which it is necessary to develop organizational structure of management of agricultural enterprise operating in the conditions of international diversification [6]. 
The purpose of this article is the establishment of a functional institutional mechanism activities and diversified businesses conglomerate to ensure the stability of its functioning in the conditions transformational processes.

\section{The Results of the Study}

The result of flow transformation processes in Ukraine is affected by the degree of activation of economic business development, so organically include the country's economy in the global Vogelpark processes with the aim of better use of external resources for the development and the location of markets for products of own production, and modernization the agricultural sector of Ukraine requires the formation of mechanisms of activity of an agrarian enterprises.

The establishment of a rational organizational management structure international diversified company's agricultural business is one of the main mechanisms that ensure the efficiency of marketing management in the conditions of transformation of economic system. Regarding organizational form, effective for agricultural production in Ukraine can be diversification of agricultural enterprises, financial-industrial groups, holdings. Because only by combining farms in the conditions of international diversification can resist monopolists. For example, the French agro-industrial Cooperative Association LeGrain includes 14 thousand producers of grain, sells grain in France, in Latin America, Asia, accumulates large quantities of grain, which will eventually sell for foreign markets at prices most favorable to farmers. Question distribution, pricing, market research is the responsibility agro-industrial enterprises $[1,5$, 8].

The formation of an international diversified company agricultural business provides the participants equality in common resources, redistribution of resources between the structural units operating on one financial result, the possible loss of one company kompensiruet profit of the group as a whole (a typical situation for international diversified agricultural business).

Businesses act as independent producers, among them will win most effective with a diversified structure, often to the detriment of corporate interests (a typical situation when investors hard supervise all members of the international diversified agricultural company business and use methods of competition to motivation of enterprises to work effectively, however, in various foreign markets may appear barriers and leaders change). Enterprises artificially establish contacts, often to the detriment of the overall result (not the typical the situation when the company sells the agricultural products of own production on unfavorable terms).

In today's changing conditions of activity of agricultural enterprises in General should respond to changes in the external environment and new market priorities that associated with tactical shifts. And this is possible only when the management of agricultural enterprises would be rational to carry out financial and industrial policy, to implement long-term and current planning, establish the necessary mobility of services and departments, especially significantly in terms of sustainable growth.

Intensive search of ways of reforming of agricultural enterprises of Ukraine, in particular farmers in terms of international diversification helps to build the new organizational 
structure of management of agricultural the company, in our opinion, will strengthen the role of the corporate center in diversified corporation; will provide an opportunity for management to provide the level of independence of structural subdivisions at each stage of the management and the strategic process, including the marketing department; ensure a system of marketing management of agricultural enterprises.

Note that in terms of international diversification domestic agricultural enterprises it is important to increase the competitiveness of the company and its products on the domestic and international markets. Therefore, for any new functional organizational the management structure of the diversified international conglomerate the company will focus rational function of capitalization and investment the managers of the company (the Director General and the administrative center), and the functions of production, processing, supply, marketing, logistics, budgeting the costs of legal regulation, staffing, international export activities, international certification activities on the level of company's departments: financial accounting Department, production and processing of agricultural products, marketing, international activity [10] (fig. 1).

\begin{tabular}{|c|}
\hline Economic support \\
\hline Information support \\
\hline Marketing support \\
\hline Staffing \\
\hline $\begin{array}{l}\text { Marketing planning activities in the context of } \\
\text { international diversification }\end{array}$ \\
\hline $\begin{array}{l}\text { Marketing research of domestic and international } \\
\text { markets }\end{array}$ \\
\hline \begin{tabular}{l} 
The formation of the product range \\
\hline Legal support
\end{tabular} \\
\hline $\begin{array}{l}\text { Organization and control of sales on the domestic and } \\
\text { international markets }\end{array}$ \\
\hline $\begin{array}{l}\text { Development of marketing communication activities on } \\
\text { domestic and international markets }\end{array}$ \\
\hline
\end{tabular}

Fig. 1. Functional institutional mechanism activities international diversified company conglomerate Source: own elaboration of the author

The presence of functional organizational management structure of the marketing Department will increase the participation of agricultural enterprises of Ukraine in the work of international agricultural organizations; ensure the competitiveness of agricultural production on the domestic and international markets, will strengthen the position of enterprises in international markets and will provide access to new markets; will increase the volume of sales of agricultural products on the international market in 
2- 3 times; strengthen the international orientation of the agricultural sector taking into account the trends of development of markets of individual countries; due to the geographical diversification of the international markets selling agricultural products.

Thus, in this organizational and management structure of any agricultural enterprise will turn into a diversified conglomerate structure, namely, agricultural enterprise, operating on domestic and international markets, combining production, processing units, sales departments.

Therefore, regardless of the form of institutional arrangements, structures, Association of departments of agricultural enterprises with different types of activities by type of holding have advantages over the highly specialized agricultural enterprises.

Based on the marketing mechanism of enterprise management in the conditions of international diversification proposed a new functional organizational structure of management an international diversified conglomerate company, which will be rational today for the domestic agrarian enterprises of different types, such as combining units of mixed type use the advantages of financial and industrial Corporation and classic holding (Fig. 2).

Competitive in the international markets are large enterprises, and therefore the most appropriate would be to build a diversified international conglomerate company, whose formation would take place by attaching (purchase, acquisitions, etc) other agricultural, processing and trade enterprises on the basis of the principles of the Corporation and the holding company.

In order to build a business structure that best meets the specified guidelines, consider the following factors: composition of the group of units (features of the objects included in it), the possibility of restructuring, promising areas of growth.

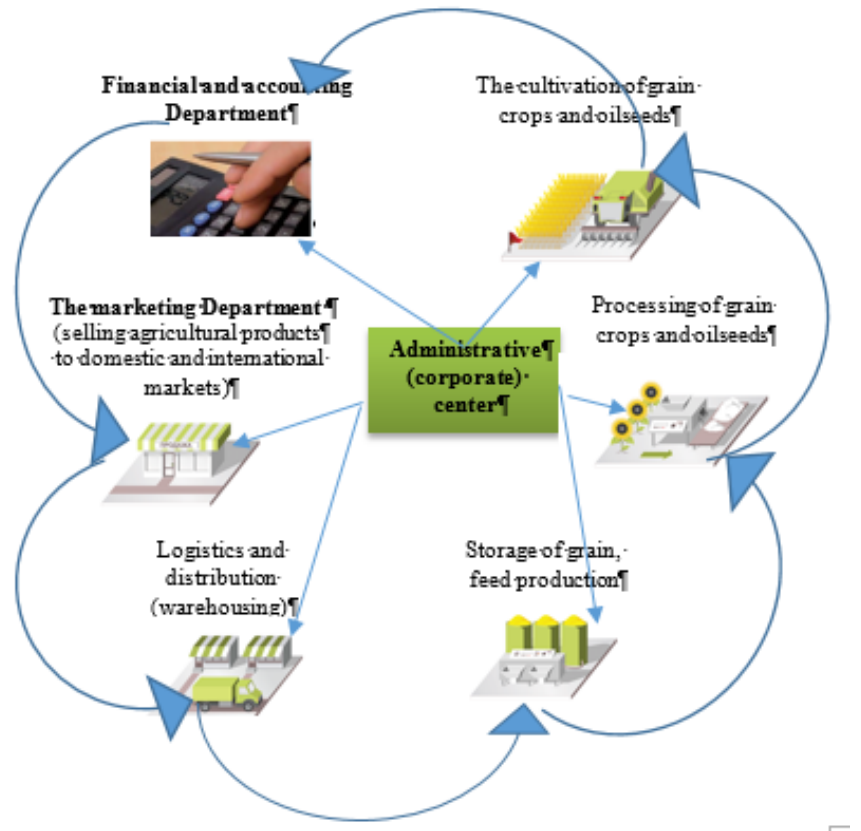

Fig. 2. The organizational-economic structure diversified conglomerate company

Source: own elaboration of the author 
Consequently, this will help to identify the types of activities in which the new company will be able to stay ahead of competitors, and business owners - to analyze the activity of all the participants of the conglomerate and in time to eliminate inefficient (created randomly).

Special attention should be given to defining the necessary degree of managerial mobility the new enterprise, the distribution of management tasks, the load on the administrative building, centralised management.

After determining the nature of the relationship of business units, their functional load is necessary to establish a full-fledged marketing management the current international diversified conglomerate company that will provide an opportunity to enhance efficiency and competitiveness in domestic and international markets.

In Ukraine, the formation of such a new international diversified conglomerate of enterprises with small businesses, by grouping farms (where the number in Ukraine most of all) will provide the opportunity to overcome the grinding of the domestic agrarian business, will provide the consolidation of the agricultural sector and creates an opportunity to benefit for the country's budget from the newly established large agricultural enterprises.

\section{Conclusions}

Therefore, developed a functional institutional mechanism activities and diversified businesses conglomerate is component of the marketing mechanism of enterprise management in conditions international diversification is based on the development of the relevant market conditions functional organizational management structure.

The introduction of this mechanism provides for the allocation of Generaland specific marketing functions with their differentiation of internal and international markets; identification and grouping of farms that carry out manufacture of agricultural production, its processing and sale on the domestic and foreign markets; the formation of the appropriate legal structure the purpose of maximum facilitation and implementation of agricultural enterprises the marketing strategy of diversification, ensure a positive outcome from overcoming crushing domestic agricultural business, consolidation the agricultural sector and the creation of opportunities to benefit for the budget Ukraine international diversified conglomerate business structures.

\section{Acknowledgment}

The author would like to thank Pavlenko A. F. of the KNEU named after Vadym Hetman for their help and support in making this work possible. This work might not have been possible had it not been for the efforts of the prior European journal of sustainable development. Their work still lives on to some degree within European journal of sustainable development. 


\section{References}

[1] A. Pavlenko, A. Vojchak «Marketing». Kyiv: KNEU, 2001, 106 p.

[2] Ye. Golubkov «Basics of marketing». Moskow: Fy`npress, 1999, 656 p.

[3] S. Pivovarova, L. Barkana «International management». St. Petersburg: St. Petersburg. «Peter», 2000, pp. 206-217.

[4] N. Didenko, D. Skripnyuk «International marketing: theory and analysis of specific situations». Moskow: Yurayt, 2016, $556 \mathrm{p}$.

[5] N. Moiseyeva «International Marketing». Moskow: Tsentr ekonomiki i marketing, 1998, 408 p.

[6] Rating of the 20 most effective agro companies in Ukraine. Available at http://forbes.net.ua/magazine/forbes/1399408-rejting-20-samyh-effektivnyh-agrokompanij _ ukrainy.

[7] N. Anistratenko «International management of marketing activity in the conditions of European integration of Ukraine». Problemy teoriyi ta metodolohiyi bukhhalters'koho obliku, kontrolyu i analizu, 2015, 2 (32), 13-23.

[8] F. Kotler, G. Armstrong «The basics of marketing». Moskow: Vil yami, 1999.

[9] Madjaro S. «International makteting». Moskow, 1977.

[10] O. Kovinko (A. Tanasiichuk) «Marketing mechanism of enterprise management in the conditions of international business diversification»: Dissertation for obtaining a scientific degree of the doctor of economic sciences. Available at: http://abstracts.donnu.edu.ua /article/view/5658/5684.

[11] A. Kozak, I. Lytovchenko, V. Jsipov, V. Piddubna, M. Kochevoy, O. Zakharchenko «International marketing». Edited by Yuriy Kozak, Sáawomir Smyczek. Kiev - Katowice, 2015, 279 p. 